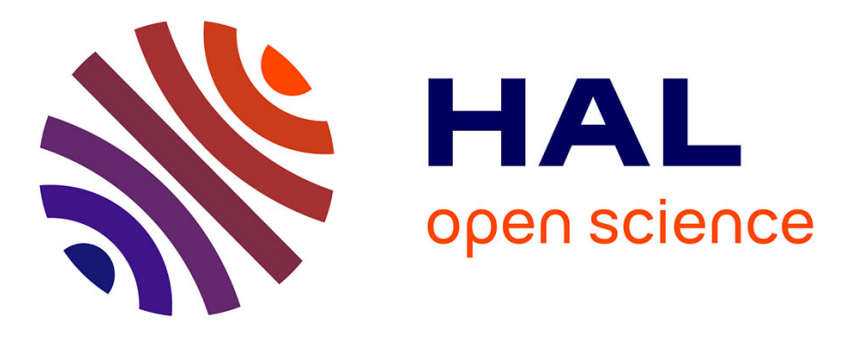

\title{
Verkade's Superbase as an Organocatalyst for the Strecker Reaction
}

\author{
Jian Yang, Bastien Chatelet, Fabio Ziarelli, Véronique Dufaud, Damien \\ Hérault, Alexandre Martinez
}

\section{- To cite this version:}

Jian Yang, Bastien Chatelet, Fabio Ziarelli, Véronique Dufaud, Damien Hérault, et al.. Verkade's Superbase as an Organocatalyst for the Strecker Reaction. European Journal of Organic Chemistry, 2018, 2018 (45), pp.6328-6332. 10.1002/ejoc.201801170 . hal-02079946

\section{HAL Id: hal-02079946 https://hal.science/hal-02079946}

Submitted on 8 Apr 2019

HAL is a multi-disciplinary open access archive for the deposit and dissemination of scientific research documents, whether they are published or not. The documents may come from teaching and research institutions in France or abroad, or from public or private research centers.
L'archive ouverte pluridisciplinaire HAL, est destinée au dépôt et à la diffusion de documents scientifiques de niveau recherche, publiés ou non, émanant des établissements d'enseignement et de recherche français ou étrangers, des laboratoires publics ou privés. 


\title{
Verkade's Superbase as an Organocatalyst for the Strecker Reaction
}

\author{
Jian Yang, ${ }^{[a]}$ Bastien Chatelet, ${ }^{[a]}$ Fabio Ziarelli, ${ }^{[b]}$ Véronique Dufaud, ${ }^{[c]}$ Damien Hérault, ${ }^{[a]}$ and \\ Alexandre Martinez*[a]
}

Abstract: Proazaphosphatranes -Verkade's superbases- proved to be efficient organocatalysts for the Strecker reaction between protected imines and trimethylsilyl cyanide (TMSCN). Excellent to quantitative yields were reached and, compared to other systems, only low catalyst loading and short reaction times were required for the reaction to proceed efficiently.
A remarkable initial turnover frequency (TOF), close to $10^{5} \mathrm{~h}^{-1}$, was achieved, associated with an excellent selectivity since no side reactions were observed. A reaction mechanism was proposed and the key role played by the apical nitrogen in the proazaphosphatrane structure was demonstrated.

\section{Introduction}

Proazaphosphatranes, also named Verkade's superbases, were first described by J. G. Verkade in $1989 .{ }^{[1]}$ In contrast to iminophosphine -phosphazenes- bases, the Verkade's superbases protonate on the phosphorus atom: upon this proton transfer, the apical nitrogen links to the positive phosphorus creating a highly stable azaphosphatrane structure. ${ }^{[2]}$ The remarkable stability of this conjugated acid renders the Verkade's superbase highly basic $\left(p K_{a}=32\right){ }^{[3]}$ one of the most basic nonionic base reported so far. Proazaphosphatranes have therefore attracted considerable interests as highly efficient basic and nucleophilic catalysts to promote a large number of reactions, such as trimerization of isocyanates, ${ }^{[4 a]}$ acylation of alcohols, ${ }^{[4 b]}$ dehydrohalogenations of alkyl halides, ${ }^{[4 c]}$ silylation of alcohols, ${ }^{[4 d, 4 e]}$ the Henry reaction, ${ }^{[4 f]}$ transesterification of esters, ${ }^{[49]}$ and additions of trimethylsilyl cyanide to aldehydes and ketones. ${ }^{[4 \mathrm{~h}]}$ The reaction conditions are generally milder with the Verkade's superbase than with other organocatalysts: lower temperatures and shorter reaction times are usually used and the reactions are often more selective. ${ }^{[4]}$ Besides this remarkable activity as organocatalyst, new aspects of the chemistry of Verkade's superbases have recently been developed, i.e. they were found to act as highly donor ligand for transition metal complexes, ${ }^{[5]}$ leading to very active organometallic catalysts, for Suzuki-Miyaura cross-coupling reactions, ${ }^{[6]}$ or Buchwald-Hartwig amination reactions of aryl chlorides. ${ }^{[7]}$ Proazaphosphatranes have also been confined in molecular cages or mesoporous silica leading to unexpected behavior and reactivity. ${ }^{[8]}$ Recently, proazaphosphatranes turned out to be remarkable catalysts for the reductive functionalization of $\mathrm{CO}_{2}$ into methylamines, in the presence of hydroborane. ${ }^{[9]}$ Moreover, Krempner et al. demonstrated that Verkade's super-bases can be used to create intermolecular frustrated Lewis pairs (FLP) when associated to a weak boroncontaining Lewis acid. ${ }^{[10]}$ These "inverse" FLPs were able to cleave dihydrogen leading to efficient hydrogenation catalysts. The same group also reported the interactions and coordination properties of Verkade's superbases with strong Lewis acids by reaction of proazaphosphatranes with various gallium-, boron- and aluminium-containing Lewis acids. ${ }^{[11]}$

Although these recent developments bring new insight into the potentiality of such structure for new applications, the classical use of the Verkade's superbases as organocatalysts remains attractive because of their high performance in term of activity and selectivity. ${ }^{[12]}$ Among the base-catalyzed transformations, the Strecker reaction is an appealing target reaction since it leads to the synthesis of $\alpha$-aminonitriles which are important and versatile building blocks in organic synthesis as well as in biologically active products. ${ }^{[13]}$ Consequently, numerous catalysts have been developed to perform this reaction. ${ }^{[14]}$ One can cite the use of Lewis acids such as $\mathrm{BiCl}_{3,}{ }^{[15]} \operatorname{InI}_{3,}{ }^{[16]}$ $\mathrm{RuCl}_{3}{ }^{[17]} \mathrm{NiCl}_{2}{ }^{[18]} \mathrm{La}\left(\mathrm{NO}_{3}\right)_{3} \cdot 6 \mathrm{H}_{2} \mathrm{O},{ }^{[19]} \mathrm{Yb}(\mathrm{OTf})_{3}{ }^{[20]} \mathrm{Sc}(\mathrm{OTf})_{3}{ }^{[21]}$ $\mathrm{Cu}(\mathrm{OTf})_{2} \cdot{ }^{[22]}$ Generally, in those reactions, the aqueous workup is tedious and a large amount of toxic metal waste is generated inevitably. A few organocatalysts have also been reported to catalyze Strecker type reactions. $\mathrm{N}$-heterocyclic carbenes were shown to catalyze the addition of trimethylsilyl cyanide to imines with excellent yields in the presence of $5 \mathrm{~mol}-\%$ catalyst loading at $0{ }^{\circ} \mathrm{C}$, but substrates were limited to tosyl protected imines, and, in most cases, long reaction times were needed (56 hours). ${ }^{[23]}$ Heydari et al. showed that guanidine hydrochloride could act as catalyst for Strecker type reactions using aliphatic, aromatic, heterocyclic conjugated aldehydes, and primary, sec- 
ondary amines as substrates. ${ }^{[24]}$ However, only moderate activity could be achieved with TON around 33 at $40{ }^{\circ} \mathrm{C}$ in 1 hour. Thiourea also performed well as catalyst with moderate to high yields in the presence of $5 \mathrm{~mol}-\%$ catalyst loading at $0{ }^{\circ} \mathrm{C}$, using primary amines and a range of aldehydes as substrates, in the presence of acyl cyanides as cyanide source. However, extended reaction times were required (1.5-2 days) for the reaction to proceed. ${ }^{[25]}$ Besides, aqueous formic acid has proven to be an environment-friendly organocatalyst for the Strecker reaction between aniline, aromatic aldehydes and TMSCN at room temperature in 5-72 min, but a higher catalyst loading was necessary (20 mol-\%) to achieve sufficient activity. ${ }^{[26]}$ Recently, an ionic liquid was reported to be an efficient organocatalyst for the strecker reaction with TOF reaching $10000000 \mathrm{~h}^{-1}$. $^{[27]} \mathrm{Al}-$ though significant progress has been made, these methodologies are far from ideal from a sustainability viewpoint and greener organocatalysts able to function under milder reaction conditions while exhibiting high turnover numbers (TONs) and initial turnover frequencies (TOFs) still need to be developed.

Herein, we report on the use of differently substituted proazaphosphatranes 1a-d (Figure 1) as catalysts for the Strecker reaction using Ts-, $\mathrm{N}$-Boc-, and $\mathrm{Bn}$ - protected imines as substrates and TMSCN as cyanide source. These catalysts proved to be highly efficient under very mild reaction conditions providing at $0{ }^{\circ} \mathrm{C}$ high TOFs around $10^{5} \mathrm{~h}^{-1}$ and TONs up to $10^{4}$. Besides, a mechanism is proposed for the cyanation of imines catalyzed by proazaphosphatranes.

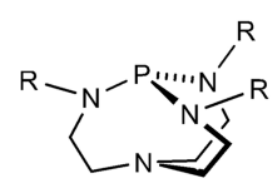

1

$$
\begin{aligned}
& \text { 1a, } \mathrm{R}=\mathrm{PMB} \\
& \text { 1b, } \mathrm{R}=i-\mathrm{Bu} \\
& 1 \mathrm{c}, \mathrm{R}=i-\mathrm{Pr} \\
& 1 \mathrm{~d}, \mathrm{R}=\mathrm{Me}
\end{aligned}
$$

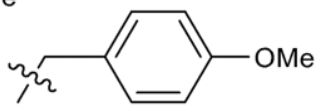

Figure 1. Proazaphosphatranes $\mathbf{1 a - 1 d}$ used in this study.

\section{Results and Discussion}

The cyanation of imines was first investigated in the presence of proazaphosphatrane $\mathbf{1} \mathbf{a}$ as catalyst using the addition of TMSCN (1.5 equiv.) to $N$-Tosyl-benzaldimine (1.0 equiv.) as a benchmark reaction (Table 1). We were pleased to observe that, in the presence of $1 \mathrm{~mol}-\%$ of proazaphosphatrane $1 \mathrm{a}$ in 20 minutes and at $0{ }^{\circ} \mathrm{C}$, more than $99 \%$ yield was reached (entry 1, Table 1), and even in very short reaction time (2 minutes), yield as high as $97 \%$ could be achieved (entry 2, Table 1), highlighting the high efficiency of the Verkade's superbase as organocatalyst for this reaction. In addition, $\mathbf{1}$ a proved to be very selective leading to $\alpha$-aminonitriles as the sole products, in line wih the results previously reported by J. G. Verkade for other transformations. ${ }^{[4]}$

Motivated by these results, we then decided to decrease the catalyst loading to explore further the performance scope of $\mathbf{1 a}$ with 0.1 mol-\% loading, $83 \%$ and $99 \%$ yields were obtained in 2 and 20 minutes respectively (entries 3 and 4 respectively,

\begin{tabular}{|c|c|c|c|}
\hline Entry & 1a (mol-\%) & Time & Yield $[\%]^{[b]}$ \\
\hline 1 & 1 & $20 \mathrm{~min}$ & $>99$ \\
\hline 2 & 1 & $2 \min$ & 97 \\
\hline 3 & 0.1 & $20 \mathrm{~min}$ & 99 \\
\hline 4 & 0.1 & $2 \min$ & 83 \\
\hline 5 & 0.01 & $20 \mathrm{~min}$ & 58 \\
\hline 6 & 0.01 & $2 \min$ & 31 \\
\hline 7 & 0.01 & $12 \mathrm{~h}$ & 99 \\
\hline 8 & - & $12 \mathrm{~h}$ & $<1$ \\
\hline
\end{tabular}
Table 1). Decreasing further the amount of $\mathbf{1 a}$ to $0.01 \mathrm{~mol}-\%$
Table 1. Optimization of catalyst loading and reaction time for proazaphosphatrane 1 a catalyzed cyanation of imines. ${ }^{[a]}$

[a] Reaction conditions: $N$-Tosyl-benzaldimine $(0.5 \mathrm{mmol})$, TMSCN (0.75 mmol), $1.5 \mathrm{~mL}$ of THF, under argon, then $3 \mathrm{~mL}$ of $\mathrm{H}_{2} \mathrm{O}$. [b] Isolated yields are given.

produced a $31 \%$ yield in only 2 minutes which corresponds to a TOF of $9.310^{4} \mathrm{~h}^{-1}$, a remarkable activity value for an organocatalyst for the Strecker reaction (entry 6, Table 1). Prolonging the reaction time at this very low catalyst loading resulted in additional activity improvement with yields attaining $58 \%$ in 20 minutes and up to $99 \%$ after 12 hours, affording a total TON around $10^{4}$ (entries 5 and 7, Table 1). It is noteworthy that no reaction occurred without catalyst (entry 8 , Table 1 ), even after 12 hours, and that $\mathrm{Et}_{3} \mathrm{~N}$ failed to catalyze this reaction when used in the same reaction conditions as in entry $3(0.1 \mathrm{~mol}-\%$, $20 \mathrm{~min}, 0{ }^{\circ} \mathrm{C},<1 \%$ yield). Thus, it appears that the Verkade's superbase is a powerful catalyst for the Strecker reaction displaying remarkable initial TOFs and TONs under mild conditions, underlining both its high catalytic activity and stability. It is worth mentioning that J. G. Verkade demonstrated in a previous report that an azaphosphatrane nitrate salt could catalyze the three-component Strecker reaction, however $20 \mathrm{~mol}-\%$ of catalyst loading and long reaction times ranging from 15 to 35 hours were needed. ${ }^{[28]}$

We then chose to use the following reaction conditions to further screen the reaction parameters and catalyst structural pattern: $0.1 \mathrm{~mol}-\%$ of catalyst loading at $0{ }^{\circ} \mathrm{C}$ for 20 minutes, as they allow for the reaction to proceed in high yield and in relatively short reaction timeframe. We first examined the influence of the solvent on catalytic performance. As shown from Table 2, high conversion levels were achieved in all the cases with yields of $93 \%$ for DCM and up to $99 \%$ for both THF and toluene (entries 1, 2, and 3, Table 2). The influence of the stereoelectronic properties and basicity of the proazaphosphatranes $\mathbf{1 a - d}$ on catalytic activity was then investigated using THF as solvent (Table 2). In the presence of $0.1 \mathrm{~mol}$ \% catalyst within $20 \mathrm{~min}-$ utes, all four proazaphosphatranes displayed excellent catalytic activity with yields approaching $100 \%$ (entries 3, 4, 5 and 6, Table 2). In order to further discriminate catalytic activity among the proazaphosphatranes $\mathbf{1} \mathbf{a}-\mathbf{d}$, a lower catalyst loading of $0.001 \mathrm{~mol}-\%$ was used within the same reaction period. The results indicated that catalytic activity was correlated to the basicity of proazaphosphatranes: stronger basicity resulted in 
higher yield (entries 3-6, Table 2). Indeed, the catalytic activity follows the same trend $(\mathbf{1} \mathbf{a}<\mathbf{1} \mathbf{d}<\mathbf{1} \mathbf{b}<\mathbf{1} \mathbf{c})$ as the basicity order of proazaphosphatranes (1a $<\mathbf{1} \mathbf{d}<\mathbf{1} \mathbf{b}<\mathbf{1 c}$ ).

Table 2. Influence of solvent and stereoelectronic properties of proazaphosphatranes on catalytic activity. ${ }^{\left[{ }^{[a]}\right.}$

\begin{tabular}{lllll} 
& & & \\
\hline
\end{tabular}

[a] Reaction conditions: $N$-Tosyl-benzaldimine $(0.5 \mathrm{mmol})$, TMSCN (0.75 mmol), $0.1 \mathrm{~mol}$ \% catalyst, $1.5 \mathrm{~mL}$ of solvent, under argon for $20 \mathrm{~min}$, then $3 \mathrm{~mL}$ of $\mathrm{H}_{2} \mathrm{O}$. [b] $\mathrm{p} K_{\mathrm{a}}$ values of conjugate acids of proazaphosphatrane bases in acetonitrile. ${ }^{[8,3]}[\mathrm{c}]$ Isolated yields are given. [d] $0.001 \mathrm{~mol}-\%$ catalyst was used for $2 \mathrm{~h}$.

With optimized conditions in hand, we then studied the scope of substrates for the cyanation of imines on representative examples. Tosyl-protected imines bearing phenyl groups differently substituted were first explored (entries 1-4, Table 3), for which nearly quantitative isolated yields were obtained. In addition to aromatic substituents, aliphatic analogue $\mathbf{2 f}$ also proceeded well with $85 \%$ yield (entry 6 , Table 3 ). Furthermore, $\mathrm{N}$-Boc and Bn-protected imines were tested in our system. Remarkably, excellent yields of $94 \%$ and $92 \%$ of corresponding products were reached, respectively (entries 7 and 8, Table 3). Clearly, different protecting groups are compatible with our methodology, which provides an attractive alternative for some specific low-reactive imines. Another key advantage is the use of TMSCN as cyanide source, which is more convenient and safer than typical cyanide salts such as $\mathrm{NaCN}, \mathrm{KCN}$ or extremely toxic ones like HCN. Cyanation of an imine bearing a heterocyclic furan group was also successfully achieved in high yield (95\%) after 2 hours (entry 9, Table 3). Using ketimine $\mathbf{2 j}$ as substrate also provides the expected product $\mathbf{3} \mathbf{j}$ in $93 \%$ yield (entry 10, Table 3).

A possible reaction mechanism is depicted in Scheme 1. The first step is the activation of TMSCN by attack of the superbase to form a tetra-coordinated silicon complex $\mathbf{A}$ which was confirmed by solid-state CP MAS ${ }^{29} \mathrm{Si}$ NMR: the appearance of a new signal was observed at 7.8 ppm by mixing 1 equiv. of TMSCN with 1 equiv. of $\mathbf{1} \mathbf{a}$, in addition to the resonance at -12.0 ppm for TMSCN, in agreement with the literature data (Figures S47-48). ${ }^{[\mathrm{h}]}$ Then, the nucleophilic anion $\mathrm{CN}^{-}$attacks the imine substrate affording the key intermediate ion pair $\mathbf{B}$. Cleavage of the Si-P bond leads to the regeneration of the catalyst $\mathbf{1 a}$ and the concomitant release of the TMS-protected amine product $\mathbf{C}$ which is subsequently hydrolyzed to give the desired amine product $\mathbf{D}$. $^{[29 a, 30]}$

In order to shed light on the nature of the high efficiency of proazaphosphatranes, we carried out a control experiment us-
Table 3. Substrate scope of proazaphosphatrane 1a-catalyzed cyanation of imines. ${ }^{[a]}$

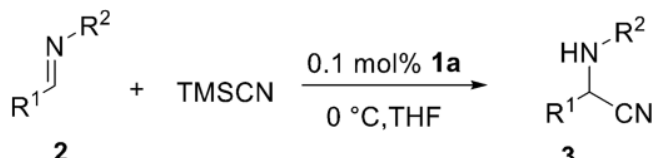

\begin{tabular}{lllllll}
\hline Entry & Imine & $\mathrm{R}^{1}$ & $\mathrm{R}^{2}$ & $\mathrm{PG}$ & Product & Yield [\%] $^{[\mathrm{b}]}$ \\
\hline 1 & $\mathbf{2 a}$ & $\mathrm{Ph}$ & $\mathrm{H}$ & Tosyl & $\mathbf{3 a}$ & quant. \\
2 & $\mathbf{2 b}$ & $p-\mathrm{MeC}_{6} \mathrm{H}_{4}$ & $\mathrm{H}$ & Tosyl & $\mathbf{3 b}$ & quant. \\
3 & $\mathbf{2 c}$ & $p-\mathrm{MeOC}_{6} \mathrm{H}_{4}$ & $\mathrm{H}$ & Tosyl & $\mathbf{3 c}$ & quant. \\
4 & $\mathbf{2 d}$ & $p-\mathrm{CNC}_{6} \mathrm{H}_{4}$ & $\mathrm{H}$ & Tosyl & $\mathbf{3 d}$ & quant. \\
5 & $\mathbf{2 e}$ & $2-$ naphthyl & $\mathrm{H}$ & Tosyl & $\mathbf{3 e}$ & quant. \\
6 & $\mathbf{2 f}$ & $t \mathrm{Bu}$ & $\mathrm{H}$ & Tosyl & $\mathbf{3 f}$ & 85 \\
7 & $\mathbf{2 g}$ & $\mathrm{Ph}$ & $\mathrm{H}$ & $N-B o c$ & $\mathbf{3 g}$ & 94 \\
8 & $\mathbf{2 h}$ & $\mathrm{Ph}$ & $\mathrm{H}$ & $\mathrm{Bn}$ & $\mathbf{3 h}$ & 92 \\
9 & $\mathbf{2 i}$ & 2 -furan & $\mathrm{H}$ & Tosyl & $\mathbf{3 i}$ & $95^{[\mathrm{ic}]}$ \\
10 & $\mathbf{2 j}$ & $\mathrm{Ph}$ & $\mathrm{CH}$ & Tosyl & $\mathbf{3 j}$ & $93^{[c, d]}$
\end{tabular}

[a] Reaction conditions: imines $(0.5 \mathrm{mmol}), \mathrm{TMSCN}(0.75 \mathrm{mmol}), 0.1 \mathrm{~mol}-\%$ 1a, $1.5 \mathrm{~mL}$ of THF, $20 \mathrm{~min}$, under argon, then $3 \mathrm{~mL}$ of $\mathrm{H}_{2} \mathrm{O}$. [b] Isolated yields are given. [c] 2 mol-\% of catalyst was used. [d] The reaction was performed for $2 \mathrm{~h}$.

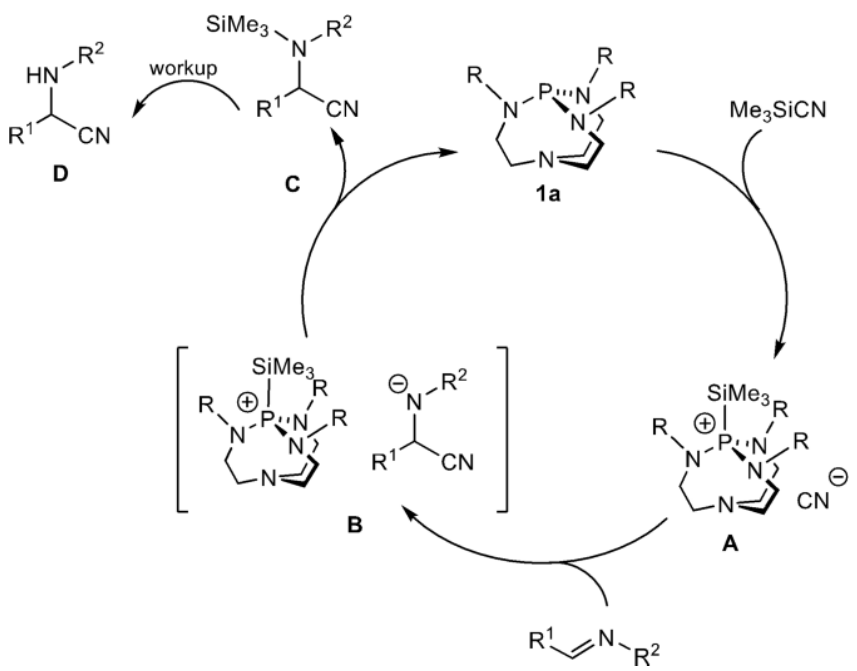

Scheme 1. Proposed mechanism for the cyanation of imines catalyzed by proazaphosphatrane.

ing $\mathrm{N}$-Tosyl-benzaldimine and TMSCN as substrates in the presence of $20 \mathrm{~mol}-\%$ of HMPT at $0{ }^{\circ} \mathrm{C}$ in THF for $24 \mathrm{~h}$ (Scheme 2). Only $23 \%$ yield was reached, which can be compared to the quantitative yield obtained with $0.1 \mathrm{~mol}$ - $\%$ of proazaphosphatrane $1 \mathbf{a}$ in only 20 minutes (entry 1, Table 3 ). As can be seen, HMPT and $1 \mathbf{a}$ have similar structure except for the bridgehead nitrogen in $\mathbf{1 a}$, the transannulation between bridgehead nitrogen and phosphorus enhanced the basicity and nucleophilicity of the phosphorus atom in $\mathbf{1} \mathbf{a}$, which makes it more reactive for activation of TMSCN in agreement with other reported proazaphosphatrane-catalyzed transformations. ${ }^{[4 h, 29 a, 30]}$

\section{Conclusions}

In summary, we have presented a mild, convenient and highly efficient methodology for the synthesis of $\alpha$-aminonitriles using 


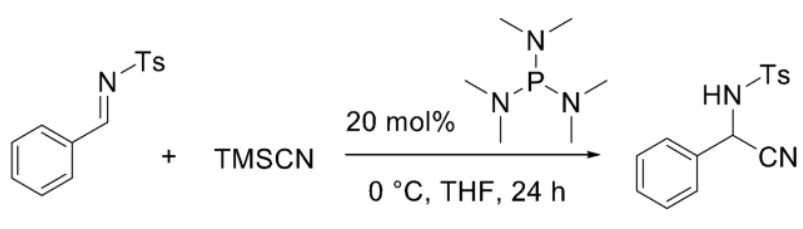

$23 \%$

Scheme 2. Cyanation of imine in the presence of HMPT.

proazaphosphatranes $\mathbf{1 a - d}$ as catalysts. In general, our method tolerates a variety of substrates, ranging from aromatic, heteroaromatic to aliphatic imines with different protecting groups including Tosyl-, Bn-, and $\mathrm{N}$-Boc. The very low catalyst loading, safer cyanide source and excellent yield and selectivity make 1a-d outstanding among the best organocatalysts for the Strecker reaction.

\section{Experimental Section}

All commercial reagents and starting materials were used directly as received without further purification. Proazaphosphatrane 1a was prepared using a reported procedure, ${ }^{[8 \mathrm{~d}]} \mathbf{1} \mathbf{b}-\mathbf{d}$ were purchased from commercial sources. All dry solvents were purified prior to use through standard procedures or obtained from a solvent drying system (MB-SPS-800). All the reactions were carried out under an atmosphere of argon, unless otherwise noted. Flash column chromatography was performed using silica gel 60 (230-400 mesh). Thin-layer chromatography was per-formed on aluminum-coated plates with silica gel $60 \mathrm{~F}_{254}$ and was visualized with a UV lamp or by staining with potassium permanganate. ${ }^{1} \mathrm{H}$ NMR spectra were recorded at either 300 or $400 \mathrm{MHz}$ on BRUKER Avance III nanobay spectrometers. ${ }^{13} \mathrm{C}$ NMR spectra were recorded at either 101 or $126 \mathrm{MHz}$ and reported in ppm relative to $\mathrm{CDCl}_{3}(\delta=77.4 \mathrm{ppm}$ ), unless otherwise noted. Single Pulse Magic Angle Spinning (CP MAS) ${ }^{29} \mathrm{Si}$ Solid State NMR spectra were obtained with a Bruker Avance $400 \mathrm{MHz}$ WB spectrometer at the ${ }^{29} \mathrm{Si}$ resonance frequency of $79.5 \mathrm{MHz}$. Chemical shifts were referenced to tetramethylsilane, whose resonance was set to $0 \mathrm{ppm}$. High-resolution mass spectra (HRMS) were performed at Spectropole Analysis Service of Aix Marseille University.

General Procedure for Proazaphosphatrane-catalyzed Cyanation of Imines: To a solution of pro-azaphosphatrane $(0.1 \% \mathrm{mmol})$ and TMSCN (94 $\mu \mathrm{L}, 0.75 \mathrm{mmol})$ in THF $(1.5 \mathrm{~mL})$ was added imine $(0.5 \mathrm{mmol})$ under an atmosphere of argon. The mixture was stirred at $0{ }^{\circ} \mathrm{C}$ for 20 minutes, upon completion monitored by TLC, $3 \mathrm{~mL}$ of $\mathrm{H}_{2} \mathrm{O}$ was added and the mixture was stirred for another 30 minutes. The reaction mixture was then extracted with ethyl acetate $(3 \times 50 \mathrm{~mL})$. The organic phase was collected, dried with anhydrous $\mathrm{Na}_{2} \mathrm{SO}_{4}$, filtered, and concentrated under vacuum. The crude product was purified by flash column chromatography using petroleum ether and ethyl acetate (10:1) as eluent to give products $\mathbf{3 a} \mathbf{a}-\mathbf{j}$. All compounds have been described elsewhere, therefore only ${ }^{1} \mathrm{H},{ }^{13} \mathrm{C}$ and mass spectra are given, which are consistent with reported literatures.

$\mathrm{N}$-[Cyano(phenyl)methyl]-4-methylbenzenesulfonamide (3a): ${ }^{[31]}$ Obtained as white solid, $143 \mathrm{mg}$ (quant.). ${ }^{1} \mathrm{H}$ NMR $\left(400 \mathrm{MHz}, \mathrm{CDCl}_{3}\right)$ : $\delta=7.81(\mathrm{~d}, J=7.8 \mathrm{~Hz}, 2 \mathrm{H}), 7.50-7.39(\mathrm{~m}, 5 \mathrm{H}), 7.37(\mathrm{~d}, J=7.8 \mathrm{~Hz}$, $2 \mathrm{H}), 5.48(\mathrm{~s}, 1 \mathrm{H}), 5.12(\mathrm{~s}, 1 \mathrm{H}), 2.46(\mathrm{~s}, 3 \mathrm{H}) \mathrm{ppm} .{ }^{13} \mathrm{C} \mathrm{NMR}(101 \mathrm{MHz}$, $\left.\mathrm{CDCl}_{3}\right): \delta=144.7,136.1,132.1,130.1,129.9,129.4,127.3,127.1$,
116.3, 48.2, 21.7 ppm. HRMS (ESI-TOF) $\mathrm{m} / \mathrm{z}$ : calcd. for $\mathrm{C}_{15} \mathrm{H}_{18} \mathrm{~N}_{3} \mathrm{O}_{2} \mathrm{~S}^{+}$ $\left[\mathrm{M}+\mathrm{NH}_{4}\right]^{+}, 304.1114$, found 304.1112 .

$\mathbf{N}$-[Cyano( $p$-tolyl)methyl]-4-methylbenzenesulfonamide (3b): ${ }^{[31]}$ Obtained as white solid, $151 \mathrm{mg}$ (quant.) ${ }^{1} \mathrm{H}$ NMR $\left(400 \mathrm{MHz}, \mathrm{CDCl}_{3}\right)$ : $\delta=7.82(\mathrm{~d}, J=8.3 \mathrm{~Hz}, 2 \mathrm{H}), 7.37(\mathrm{~d}, J=8.0 \mathrm{~Hz}, 2 \mathrm{H}), 7.32(\mathrm{~d}, J=$ $8.1 \mathrm{~Hz}, 2 \mathrm{H}), 7.21(\mathrm{~d}, J=8.0 \mathrm{~Hz}, 2 \mathrm{H}), 5.44(\mathrm{~d}, J=8.8 \mathrm{~Hz}, 1 \mathrm{H}), 4.93$ $(\mathrm{d}, J=8.8 \mathrm{~Hz}, 1 \mathrm{H}), 2.46(\mathrm{~s}, 3 \mathrm{H}), 2.36(\mathrm{~s}, 3 \mathrm{H}) \mathrm{ppm} .{ }^{13} \mathrm{C}$ NMR $\left(101 \mathrm{MHz}, \mathrm{CDCl}_{3}\right): \delta=144.68,140.12,136.11,130.05,129.15,127.36$, $126.99,116.39,48.04,21.66,21.16$ ppm. HRMS (ESI-TOF) $\mathrm{m} / \mathrm{z}$ : calcd. for $\mathrm{C}_{16} \mathrm{H}_{20} \mathrm{~N}_{3} \mathrm{O}_{2} \mathrm{~S}^{+}\left[\mathrm{M}+\mathrm{NH}_{4}\right]^{+}, 318.1271$, found 318.1272.

$\mathrm{N}$-[Cyano(4-methoxyphenyl)methyl]-4-methylbenzenesulfonamide (3c): ${ }^{[31]}$ Obtained as white solid, $158 \mathrm{mg}$ (quant.). ${ }^{1} \mathrm{H}$ NMR $\left(400 \mathrm{MHz}, \mathrm{CDCl}_{3}\right): \delta=7.81(\mathrm{~d}, J=7.1 \mathrm{~Hz}, 2 \mathrm{H}), 7.46-7.28(\mathrm{~m}, 4 \mathrm{H})$, $6.90(\mathrm{~d}, J=7.4 \mathrm{~Hz}, 2 \mathrm{H}), 5.42(\mathrm{~d}, J=8.5 \mathrm{~Hz}, 1 \mathrm{H}), 5.00(\mathrm{~d}, J=8.2 \mathrm{~Hz}$, $1 \mathrm{H}), 3.81(\mathrm{~s}, 3 \mathrm{H}), 2.46(\mathrm{~s}, 3 \mathrm{H}) \mathrm{ppm} .{ }^{13} \mathrm{C} \mathrm{NMR}\left(101 \mathrm{MHz}, \mathrm{CDCl}_{3}\right): \delta=$ $160.72,144.66,136.12,130.04,128.54,127.35,124.03,116.47$, $114.74,55.44,47.78,21.66 \mathrm{ppm}$. HRMS (ESI-TOF) $\mathrm{m} / \mathrm{z}$ : calcd. for $\mathrm{C}_{16} \mathrm{H}_{20} \mathrm{~N}_{3} \mathrm{O}_{3} \mathrm{~S}^{+}\left[\mathrm{M}+\mathrm{NH}_{4}\right]^{+}, 334.1220$, found 334.1221.

$\mathbf{N}$-[Cyano(4-cyanophenyl)methyl]-4-methylbenzenesulfonamide (3d): ${ }^{[31]}$ Obtained as white solid, $156 \mathrm{mg}$ (quant.). ${ }^{1} \mathrm{H}$ NMR (400 MHz, $\left.\mathrm{CDCl}_{3}\right): \delta=7.75(\mathrm{~d}, J=7.5 \mathrm{~Hz}, 2 \mathrm{H}), 7.69-7.50(\mathrm{~m}, 4 \mathrm{H})$, $7.34(\mathrm{~d}, J=7.1 \mathrm{~Hz}, 2 \mathrm{H}), 5.95(\mathrm{~d}, J=9.3 \mathrm{~Hz}, 1 \mathrm{H}), 5.50(\mathrm{~d}, J=9.4 \mathrm{~Hz}$, $1 \mathrm{H}), 2.45(\mathrm{~s}, 3 \mathrm{H}) \mathrm{ppm} .{ }^{13} \mathrm{C}$ NMR $\left(101 \mathrm{MHz}, \mathrm{CDCl}_{3}\right): \delta=145.12$, $137.14,135.65,133.02,130.19,127.95,127.24,117.76,115.47$, $113.73,47.75,21.69 \mathrm{ppm}$. HRMS (ESI-TOF) $\mathrm{m} / \mathrm{z}$ : calcd. for $\mathrm{C}_{16} \mathrm{H}_{13} \mathrm{~N}_{3} \mathrm{O}_{2} \mathrm{SNa}^{+}[\mathrm{M}+\mathrm{Na}]^{+}, 334.0621$, found 334.0621.

$\mathrm{N}$-[Cyano(naphthalen-2-yl)methyl]-4-methylbenzenesulfonamide (3e): ${ }^{[32]}$ Obtained as white solid, $170 \mathrm{mg}$ (quant.). ${ }^{1} \mathrm{H}$ NMR $\left(400 \mathrm{MHz}, \mathrm{CDCl}_{3}\right): \delta=7.97-7.78(\mathrm{~m}, 6 \mathrm{H}), 7.56(\mathrm{~d}, J=4.5 \mathrm{~Hz}, 2 \mathrm{H})$, $7.47(\mathrm{~d}, J=8.7 \mathrm{~Hz}, 1 \mathrm{H}), 7.36(\mathrm{~d}, J=8.0 \mathrm{~Hz}, 2 \mathrm{H}), 5.65(\mathrm{~d}, J=8.8 \mathrm{~Hz}$, $1 \mathrm{H}), 5.12(\mathrm{~d}, J=9.1 \mathrm{~Hz}, 1 \mathrm{H}), 2.45(\mathrm{~s}, 3 \mathrm{H}) \mathrm{ppm} .{ }^{13} \mathrm{C}$ NMR $(101 \mathrm{MHz}$, $\left.\mathrm{CDCl}_{3}\right): \delta=144.77,136.08,133.54,132.87,130.08,129.70,129.18$, $128.24,127.78,127.49,127.37,127.17,126.66,123.91,116.26,48.47$, 21.66 ppm. HRMS (ESI-TOF) m/z: calcd. for $\mathrm{C}_{19} \mathrm{H}_{20} \mathrm{~N}_{3} \mathrm{O}_{2} \mathrm{~S}^{+}\left[\mathrm{M}+\mathrm{NH}_{4}\right]^{+}$, 354.1271 , found 354.1270 .

$\mathrm{N}$-(1-Cyano-2,2-dimethylpropyl)-4-methylbenzenesulfonamide (3f): ${ }^{[33]}$ Obtained as white solid, $133 \mathrm{mg}(85 \%) .{ }^{1} \mathrm{H}$ NMR $(400 \mathrm{MHz}$, $\left.\mathrm{CDCl}_{3}\right): \delta=7.79(\mathrm{~d}, J=8.1 \mathrm{~Hz}, 2 \mathrm{H}), 7.35(\mathrm{~d}, J=7.8 \mathrm{~Hz}, 2 \mathrm{H}), 5.68$ $(\mathrm{d}, J=10.2 \mathrm{~Hz}, 1 \mathrm{H}), 3.88(\mathrm{~d}, J=10.3 \mathrm{~Hz}, 1 \mathrm{H}), 2.43(\mathrm{~s}, 3 \mathrm{H}), 1.04(\mathrm{~s}$, $9 \mathrm{H}) \mathrm{ppm} .{ }^{13} \mathrm{C}$ NMR $\left(101 \mathrm{MHz}, \mathrm{CDCl}_{3}\right): \delta=144.49,136.02,130.04$, $127.23,116.68,54.69,35.30,25.66,21.63 \mathrm{ppm}$. HRMS (ESI-TOF) $\mathrm{m} / \mathrm{z}$ : calcd. for $\mathrm{C}_{13} \mathrm{H}_{22} \mathrm{~N}_{3} \mathrm{O}_{2} \mathrm{~S}^{+}\left[\mathrm{M}+\mathrm{NH}_{4}\right]^{+}, 284.1427$, found 284.1422 .

tert-Butyl [Cyano(phenyl)methyl]carbamate (3g): ${ }^{[24]}$ Obtained as white solid, $110 \mathrm{mg}(94 \%)$. ${ }^{1} \mathrm{H}$ NMR $\left(400 \mathrm{MHz}, \mathrm{CDCl}_{3}\right): \delta=7.60-$ $7.30(\mathrm{~m}, 5 \mathrm{H}), 5.80(\mathrm{~s}, 1 \mathrm{H}), 5.16(\mathrm{~s}, 1 \mathrm{H}), 1.48(\mathrm{~s}, 9 \mathrm{H}) \mathrm{ppm} .{ }^{13} \mathrm{C}$ NMR $\left(101 \mathrm{MHz}, \mathrm{CDCl}_{3}\right): \delta=154.17,133.49,129.50,129.32,126.89,117.74$, $81.60,46.13,28.24 \mathrm{ppm}$. HRMS (ESI-TOF) $\mathrm{m} / \mathrm{z}$ : calcd. for $\mathrm{C}_{13} \mathrm{H}_{16} \mathrm{~N}_{2} \mathrm{O}_{2} \mathrm{Na}^{+}\left[\mathrm{M}+\mathrm{Na}^{+}, 255.1104\right.$, found 255.1104 .

2-(Benzylamino)-2-phenylacetonitrile (3h): ${ }^{[33]}$ Obtained as yellow oil, $102 \mathrm{mg}(92 \%) .{ }^{1} \mathrm{H}$ NMR $\left(400 \mathrm{MHz}, \mathrm{CDCl}_{3}\right): \delta=7.66-7.28(\mathrm{~m}, 10$ H), $4.77(\mathrm{~s}, 1 \mathrm{H}), 4.08(\mathrm{~d}, J=13.1 \mathrm{~Hz}, 1 \mathrm{H}), 3.97(\mathrm{~d}, J=13.0 \mathrm{~Hz}, 1 \mathrm{H})$, $1.89(\mathrm{~s}, 1 \mathrm{H}) \mathrm{ppm} .{ }^{13} \mathrm{C}$ NMR $\left(101 \mathrm{MHz}, \mathrm{CDCl}_{3}\right): \delta=138.17,134.81$, $129.05,128.99,128.67,128.44,127.67,127.33,118.78,53.49,51.29$ ppm. HRMS (ESI-TOF) $\mathrm{m} / \mathrm{z}$ : calcd. for $\mathrm{C}_{15} \mathrm{H}_{15} \mathrm{~N}_{2}{ }^{+}[\mathrm{M}+\mathrm{H}]^{+}, 223.1230$, found 223.1228 .

$\mathrm{N}$-[Cyano(furan-2-yl)methyl]-4-methylbenzenesulfonamide (3i): ${ }^{[33]}$ Obtained as colorless solid, $131 \mathrm{mg}(95 \%){ }^{1} \mathrm{H}$ NMR (400 MHz, $\left.\mathrm{CDCl}_{3}\right): \delta=7.76(\mathrm{~d}, J=8.1 \mathrm{~Hz}, 2 \mathrm{H}), 7.39-7.35(\mathrm{~m}, 1 \mathrm{H})$, $7.32(\mathrm{~d}, J=8.1 \mathrm{~Hz}, 2 \mathrm{H}), 6.45(\mathrm{~d}, J=3.2 \mathrm{~Hz}, 1 \mathrm{H}), 6.33(\mathrm{t}, J=2.5 \mathrm{~Hz}$, $1 \mathrm{H}), 5.71(\mathrm{~d}, J=8.9 \mathrm{~Hz}, 1 \mathrm{H}), 5.52(\mathrm{~d}, J=9.0 \mathrm{~Hz}, 1 \mathrm{H}), 2.43(\mathrm{~s}, 3 \mathrm{H})$ 
ppm. ${ }^{13} \mathrm{C}$ NMR $\left(75 \mathrm{MHz}, \mathrm{CDCl}_{3}\right): \delta=144.63,144.43,144.14,136.09$, $129.97,127.25,114.68,110.97,110.36,42.26,21.60$ ppm. HRMS (ESITOF) $\mathrm{m} / \mathrm{z}$ : calcd. for $\mathrm{C}_{13} \mathrm{H}_{16} \mathrm{~N}_{3} \mathrm{O}_{3} \mathrm{~S}^{+}\left[\mathrm{M}+\mathrm{NH}_{4}\right]^{+}, 294.0907$, found 294.0907.

N-(1-Cyano-1-phenylethyl)-4-methylbenzenesulfonamide (3j): ${ }^{[34]}$ Obtained as colorless solid, $139 \mathrm{mg}(93 \%){ }^{1} \mathrm{H}$ NMR (400 MHz, $\left.\mathrm{CDCl}_{3}\right): \delta=7.61(\mathrm{~d}, J=8.0 \mathrm{~Hz}, 2 \mathrm{H}), 7.48(\mathrm{~d}, J=7.2 \mathrm{~Hz}$, $2 \mathrm{H}), 7.38-7.28(\mathrm{~m}, 3 \mathrm{H}), 7.26-7.18(\mathrm{~m}, 2 \mathrm{H}), 5.40(\mathrm{~s}, 1 \mathrm{H}), 2.42(\mathrm{~s}, 3$ $\mathrm{H}), 1.94(\mathrm{~s}, 3 \mathrm{H}) \mathrm{ppm} .{ }^{13} \mathrm{C}$ NMR $\left(75 \mathrm{MHz}, \mathrm{CDCl}_{3}\right): \delta=144.05,137.38$, $137.19,129.56,129.24,128.90,127.47,125.58,118.94,56.62,30.17$, 21.55 ppm. HRMS (ESI-TOF) m/z: calcd. for $\mathrm{C}_{16} \mathrm{H}_{20} \mathrm{~N}_{3} \mathrm{O}_{2} \mathrm{~S}^{+}\left[\mathrm{M}+\mathrm{NH}_{4}\right]^{+}$, 318.1271 , found 318.1271 .

[1] a) C. Lensink, S.-K. Xi, L. M. Daniels, J. G. Verkade, J. Am. Chem. Soc. 1989 111, 3478-3479; b) M. A. Laramay, J. G. H. Verkade, J. Am. Chem. Soc. 1990, 112, 9421-9422; c) J.-S. Tang, J. G. Verkade, J. Am. Chem. Soc. 1993, 115, 1660-1664; d) J.-S. Tang, J. G. Verkade, Tetrahedron Lett. 1993, 34, 2903-2904.

[2] J. G. Verkade, P. B. Kisanga, Tetrahedron 2003, 59, 7819-7858.

[3] P. B. Kisanga, J. G. Verkade, R. Schwesinger, J. Org. Chem. 2000, 65, 54315432.

[4] a) a) J.-S. Tang, J. G. Verkade, Angew. Chem. Int. Ed. Engl. 1993, 32, 896898; Angew. Chem. 1993, 105, 934-936; b) B. A. D'Sa, J. G. Verkade, J. Org. Chem. 1996, 61, 2963-2966; c) S. Arumugam, J. G. Verkade, J. Org. Chem. 1997, 62, 4827-4828; d) B. A. D'Sa, J. G. Verkade, J. Am. Chem. Soc. 1996, 118, 12832-12833; e) B. A. D'Sa, D. McLeod, J. G. Verkade, J. Org. Chem. 1997, 62, 5057-5061; f) P. B. Kisanga, J. G. Verkade, J. Org. Chem. 1999, 64, 4298-4303; g) P. Ilankumaran, J. G. Verkade, J. Org. Chem. 1999, 64, 3086-3089; h) Z. Wang, B. Fetterly, J. G. Verkade, J. Organomet. Chem. 2002, 646, 161-166.

[5] a) Z. Thammavongsy, J. F. Khosrowabadi Kotyk, C. Tsay, J. Y. Yang, Inorg. Chem. 2015, 54, 11505-11510; b) Z. Thammavongsy, I. M. Kha, J. W. Ziller, J. Y. Yang, Dalton Trans. 2016, 45, 9853-9859; c) B. Chatelet, P. Nava, H. Clavier, A. Martinez, Eur. J. Inorg. Chem. 2017, 37, 4311-4316

[6] J. V. Kingston, J. G. Verkade, J. Org. Chem. 2007, 72, 2816-2822.

[7] S. Urgaonkar, J. H. Xu, J. G. Verkade, J. Org. Chem. 2003, 68, 8416-8423

[8] a) P. D. Raytchev, A. Bendjeriou, J.-P. Dutasta, A. Martinez, V. Dufaud, Adv. Synth. Catal. 2011, 353, 2067-2077; b) P. D. Raytchev, L. Roussi, J.-P. Dutasta, A. Martinez, V. Dufaud, Catal. Commun. 2012, 28, 1-4; c) P. Dimitrov Raytchev, A. Martinez, H. Gornitzka, J.-P. Dutasta, J. Am. Chem. Soc. 2011, 133, 2157-2159; d) B. Chatelet, H. Gornitzka, V. Dufaud, E. Jeanneau, J.-P. Dutasta, A. Martinez, J. Am. Chem. Soc. 2013, 135, 1865918664.

[9] E. Blondiaux, J. Pouessel, T. Cantat, Angew. Chem. Int. Ed. 2014, 53, 12186-12190; Angew. Chem. 2014, 126, 12382; E. Blondiaux, J. Pouessel, T. Cantat, Angew. Chem. Int. Ed. 2014, 53, 12186-12386; Angew. Chem. 2014, 126, 12382

[10] S. Mummadi, D. K. Unruh, J. Zhao, S. Li, C. Krempner, J. Am. Chem. Soc 2016, 138, 3286-3289.
[11] S. Mummadi, D. Kenefake, R. Diaz, D. K. Unruh, C. Krempner, Inorg. Chem. 2017, 56, 10748-10759.

[12] X. Wang, Y. Liu, Z. Li, H. Wang, H. Gebru, S. Chen, H. Zhu, F. Wei, K. Guo, ACS Macro Lett. 2017, 6, 1331-1336.

[13] a) P. L. Feldman, M. F. Brackeen, J. Org. Chem. 1990, 55, 4207-4209; b) P. L. Feldman, M. K. James, M. F. Brackeen, J. M. Bilotta, S. V. Schuster, A. P. Lahey, M. W. Lutz, M. R. Johnson, M. J. Leighton, J. Med. Chem. 1991, 34, 2202-2208; c) A. J. Walz, F. L. Hsu, Tetrahedron Lett. 2014, 55, 501502; d) F. G. Zhang, X. Y. Zhu, S. Li, J. Nie, J. A. Ma, Chem. Commun. 2012 48, 11552-11554; e) A. Sadhukhan, S. Saravanan, N. U. H. Khan, R. I. Kureshy, S. H. Abdi, SH. C. Bajaj, J. Org. Chem. 2012, 77, 7076-7080; f) C. Bolm, R. Mocci, C. Schumacher, M. Turberg, F. Puccetti, J. G. Hernandez, Angew. Chem. Int. Ed. 2018, 57, 2423-2426; Angew. Chem. 2018, 130, 2447-2450.

[14] For reviews, see: a) H. Gröger, Chem. Rev. 2003, 103, 2795-2828; b) J. Wang, X. Liu, X. Feng, Chem. Rev. 2011, 111, 6947-6983; c) L. Yet, Angew. Chem. Int. Ed. 2001, 40, 875-877; Angew. Chem. 2001, 113, 900-902; d) P. Merino, E. Marqués-López, T. Tejero, R. P. Herrera, Tetrahedron 2009 65, 1219-1234; e) V. V. Kouznetsov, C. E. P. Galvis, Tetrahedron 2018, 74, $773-810$.

[15] S. K. De, R. A. Gibbs, Tetrahedron Lett. 2004, 45, 7407-7408.

[16] Z. L. Shen, S. J. Ji, T. P. Loh, Tetrahedron 2008, 64, 8159-8163.

[17] S. K. De, Synth. Commun. 2005, 35, 653-656.

[18] S. K. De, J. Mol. Catal. A 2005, 225, 169-171.

[19] M. Narasimhulu, T. S. Reddy, K. C. Mahesh, S. M. Reddy, A. V. Reddy, Y. Venkateswarlu, J. Mol. Catal. A 2007, 264, 288-292.

[20] S. Kobayashi, H. Ishitani, M. Ueno, Synlett 1997, 115-116.

[21] S. Kobayashi, T. Busujima, Chem. Commun. 1998, 981-982.

[22] A. S. Paraskar, A. Sudalai, Tetrahedron Lett. 2006, 47, 5759-5762.

[23] a) Y. Fukuda, Y. Maeda, K. Kondo, T. Aoyama, Synthesis 2006, 12, 1937 1939; b) Y. Fukuda, K. Kondo, T. Aoyama, Synthesis 2006, 16, 2649-2652.

[24] A. Heydari, A. Arefi, S. Khaksar, R. K. Shiroodi, J. Mol. Catal. A 2007, 271, 142-144.

[25] S. C. Pan, B. List, Synlett 2007, 2, 318-320.

[26] H. Ghafuri, M. Roshani, RSC Adv. 2014, 4, 58280-58286.

[27] B. Ullah, J. Chen, Z. Zhang, H. Xing, Q. Yang, Z. Bao, Q. Ren, Scientific Reports https://doi.org/10.1038/srep42699.

[28] B. M. Fetterly, N. K. Jana, J. G. Verkade, Tetrahedron 2006, 62, 440-456.

[29] a) K. Wadhwa, V. R. Chintareddy, J. G. Verkade, J. Org. Chem. 2009, 74, 6681-6690; b) P. B. Kisanga, P. Ilankumaran, B. M. Fetterly, J. G. Verkade, J. Org. Chem. 2002, 67, 3555-3560; C) B. A. D'Sa, P. Kisanga, J. G. Verkade, J. Org. Chem. 1998, 63, 3961-3967.

[30] V. R. Chintareddy, K. Wadhwa, J. G. Verkade, J. Org. Chem. 2009, 74, 8118 8132.

[31] S. T. Kadam, P. Thirupathi, S. S. Kim, Synthesis 2011, 6, 919-923.

[32] J. Wang, X. Hu, J. Jiang, S. Gou, X. Huang, X. Liu, X. Feng, Angew. Chem. Int. Ed. 2007, 46, 8468-8470; Angew. Chem. 2007, 119, 8620-8622.

[33] N. H. Khan, S. Agrawal, R. I. Kureshy, S. H. R. Abdi, S. Singh, E. Suresh, R. V. Jasra, Tetrahedron Lett. 2008, 49, 640-644.

[34] X. Huang, J. Huang, Y. Wen, X. Feng, Adv. Synth. Catal. 2006, 348, 25792584 